Nadwa | Jurnal Pendidikan Islam

Vol. 9, Nomor 1, April 2015

\title{
Desain Model Manajemen Pemasaran Berbasis Layanan Jasa Pendidikan pada MTs Swasta Se-Kota Semarang
}

\author{
Fatkuroji \\ Universitas Islam Negeri Walisongo Semarang \\ Email: fatkurozi@rocketmail.com
}

\begin{abstract}
Abstrak
Penelitian ini dimaksudkan untuk mengembangkan model manajemen pemasaran berbasis layanan pendidikan yang layak untuk meningkatkan layanan jasa MTs Swasta di Kota Semarang. Hasil penelitian menunjukkan pelaksanaan desain model pengembangan manajemen pemasaran berbasis layanan jasa terdiri atas tiga fungsi yaitu: (1) perencanaan terdiri atas: (a) analisis kebutuhan konsumen, b) program layanan pendidikan MTs, c) analisis Swot MTs, d) Visi-misi \& tujuan MTs, e) kebijakan layanan MTs; (2) pelaksanaan terdiri atas: a) implementasi program layanan MTs, b) kebijakan strategi 7P+1, c) Target \& segment pasar MTs, d) kepuasan konsumen, e) relevansi kebutuhan dan layanan; (3) evaluasi terdiri atas: a) loyalitas konsumen, b) animo pendaftaran siswa ke MTs.
\end{abstract}

Kata kunci: Manajemen, Pemasaran, Layanan Jasa Pendidikan

\begin{abstract}
This study aimed to develop a management model based marketing services proper education to increase the services of Private MTs in Semarang. The results showed the implementation of the model design management development based marketing services consist of three functions: (1) planning consists of: (a) analysis of consumer needs, $b$ ) education outreach programs MTs, c) a SWOT analysis of MTs, d) Vision-Mission \& destination MTs, e) service policy MTs; (2) The implementation consists of: a) the implementation of MTs service program, $b$ ) a policy strategy $7 P+1, c)$ Target \& MTs market segment, d) consumer satisfaction, $e)$ the relevance of the needs and services; (3) The evaluation consists of: a) customer loyalty, $b$ ) the interest of student enrollment to MTs.
\end{abstract}

Keywords: Management, Marketing, Education Services 


\section{Pendahuluan}

Apa itu madrasah, apa yang terbayang saat orang menyebut kata madrasah. Sebagian orang punya kesan masyarakat identik dengan bagunan kumuh, kumpulan anak-anak lusuh, hanya belajar agama tidak bisa lanjut, generasi islam yang kaku dan radikal. Lulusan madrasah identik jadi ustad, guru ngaji atau pegawai rendahan. Orang tua yang anaknya ingin jadi dokter, insiyur atau bekerja di perusahaan multinasional biasanya tidak akan menyekolahkan anaknya di madrasah. Madrasah sering dianggap tempat pembuangan anak-anak tak berprestasi, karena anak yang berprestasi masuk seklah-sekolah faforit. Madrasah menjadi sekolah pilihan alternatif setelah pilihan utama tidak diterima, kesan masyarakat pembelajaran di madrasah masih terbelakang dan jauh dari kualitas yang diharapkan masyarakat.

Saat ini belum banyak Madrasah Tsanawiyah yang melakukan manajemen pemasaran jasa pendidikan dengan baik, walaupun mereka meyakini bahwa kunci utama untuk memenangkan persaingan dalam dunia pendidikan yang semakin ketat adalah melakukan manajemen pemasaran jasa pendidikan yang baik. Madrasah Tsanawiyah yang tidak baik dalam manajemen pemasaran berbasis layanan pendidikan dapat dilihat dari beberapa indikator diantaranya: (1) profesionalisme manajemen pembelajaran yang masih rendah, (2) model pembelajaran pendidikan masih menekankan kepada pendekatan konvensional, sehingga sistem pendidikannya masih mandul, terbelakang dan mematikan daya kritis anak, (3) masih lemahnya komitmen birokrat dan pengelola Madrasah untuk mencapai keunggulan serta kurangnya kecakapan mereka dalam mengelola Madrasah, (4) tidak sedikit dari para guru yang tidak memiliki latar belakang disiplin ilmu pendidikan dan (5) tercerabutnya fungsi madrasah dalam memberikan pengetahuan, ketrampilan, keahlian, dan nilai-nilai moral serta sepiritual pada siswa. ${ }^{1}$

Kesan masyarakat dan fakta di atas menjadi persoalan yang memerlukan solusi bagaimana mengatasinya. Salah satu jawabannya karena lemahnya manajemen pemasaran layanan jasa di madrasah. Pemasaran bagi madrasah sangatlah penting, dikarenakan pertama, sebagai lembaga nonprofit yang bergerak dalam bidang jasa pendidikan, perlu meyakinkan masyarakat dan pelanggan pendidikan

${ }^{1}$ Haidar Putra Daulay. Pendidikan Islam dalam Sistem Pendidikan Nasional di Indonesia. Jakarta : Kencana. 2007. Hal. 10 
bahwa lembaga pendidikan kita masih tetap eksis, kedua, kita perlu meyakinkan masyarakat dan "pelanggan" bahwa layanan jasa madrasah yang kita lakukan sungguh relevan dengan kebutuhan mereka, ketiga, kita perlu melakukan kegiatan pemasaran agar jenis dan macam jasa layanan madrasah yang kita berikan dapat dikenal dan dimengerti secara luas oleh masyarakat, apalagi "pelanggan" keempat, tuntutan masyarakat yang tinggi terhadap mutu Madrasah, dan adanya persaingan antar madrasah/sekolah semakin atraktif.

Sementara hasil riset yang disampikan oleh Akroush merekomendasikan bahwa bauran pemasaran tidak harus 7P hanya service product, price, promotion, distribution, service people yang optimal dibanding yang lain ${ }^{2}$. Penelitian Mohammed \& Madanat (2015) 4Ps: A Strategy to Secure Customers' Loyalty via Customer Satisfaction. Hasil penelitian menunjukkan empat aspek bauran pemasaran sama-sama penting dan ketidakseimbangan di antara empat aspek bauran pemasaran dapat merusak hasil keseluruhan. Keberhasilan empat aspek tersebut berdampak pada kepuasan pelanggan berubah menjadi loyalitas. ${ }^{3}$ Berdasarkan fenomena dan research gap tersebut diatas maka perlu ada penelitian lanjutan tentang bagaimana desain model manajemen pemasaran lembaga pendidikan berbasis layanan jasa madrasah.

Adapun rumusan masalah adalah "Bagaimana desain model manajemen pemasaran berbasis layanan pendidikan pada MTs Swasta se Kota Semarang? Rumusan masalah ini meliputi : (1) bagaimanakah desain proses pembelajaran yang tepat, bagaimana desain produk pendidikan; bagaimana desain kompetensi guru-gurunya; bagaimana desain kelengkapan sarana dan prasarananya; bagaimanakah desain akses lokasi ke madrasah stanawiyahnya; bagaimana desain tarif layanan yang ditetapkan sesuai dengan kualitas pendidikan; bagaimana desain layanan promosi; bagaimanakah desain target pemasaran; dan bagaimanakah desain segmentasi pasar.

\footnotetext{
${ }^{2}$ Mamoun N. Akroush, 2011. "The 7Ps Classification of the Services
} Marketing Mix Revisited: An Empirical Assessment of their Generalisability, Applicability and Effect on Performance Evidence from Jordan's Services Organisations". Jordan Journal of Business Administration, Volume 7, No. 1.

${ }^{3}$ Mohammed T. Nuseir \& Hilda Madanat, 2015. 4Ps: A Strategy to Secure Customers' Loyalty via Customer Satisfaction. International Journal of Marketing Studies; Vol. 7, No. 4; 2015 ISSN 1918-7203 


\section{Kerangka Teoretis}

\section{Pemasaran}

Era globalisasi yang sangat kompetitif, pemasaran diibaratkan sebagai denyut jantung bagi kelangsungan organisasi pendidikan yang bergerak dalam bidang layanan jasa, pemasaran harus bertitik tolak dari kebutuhan dan keinginan konsumen dengan memperkirakan sekaligus menentukan kebutuhan dan keinginan konsumen serta penyerahan barang dan jasa yang memuaskan secara efektif dan efisien.

Kotler menyatakan pemasaran adalah suatu proses sosial yang didalamnya individu dan kelompok mendapatkan apa yang mereka butuhkan dan inginkan dengan menciptakan, menawarkan, dan secara bebas mempertukarkan produk yang bernilai dengan pihak lain. ${ }^{4}$ Dari pengertian ini, pemasaran menurut Philip Kotler merupakan suatu proses penukaran produk atau perpindahan hak milik, dalam hal ini adalah pertukaran benda-benda yang benilai bagi manusia berupa barang dan jasa serta uang untuk kelangsungan hidupnya

Sedangkan menurut Walker dan Larroche, pemasaran adalah suatu proses sosial yang melibatkan kegiatan-kegiatan penting yang memungkinkan individu dan perusahaan mendapatkan apa yang mereka butuhkan dan inginkan melalui pertukaran dengan pihak lain dan untuk mengembangkan hubungan pertukaran ${ }^{5}$.

Jadi pemasaran merupakan salah satu dari kegiatan pokok yang dilakukan oleh para produsen dalam mempertahankan kontiunitas usahanya untuk mendapatkan laba. Berhasil tidaknya suatu usaha, tergantung keahlian mereka dalam pemasaran, produksi, maupun bidang lain, serta pada kemampuan produsen untuk mengkomunikasikan fungsi-fungsi tersebut agar organisasi usaha dapat berjalan lancar.

\section{a. Pemasaran Jasa}

Jasa merupakan suatu fenomena yang sangat rumit. Kata jasa mempunyai banyak arti dan ruang lingkup, dari pengertian yang paling sederhana, yaitu hanya berupa pelayanan dari seseorang kepada orang lain, bisa juga diartikan sebagai mulai dari pelayanan

${ }^{4}$ Kotler, Philip. 2002. Manajemen Pemasaran. Jilid 2. Jakarta. Bumi Aksara.

${ }^{5}$ Boyd, Walker dan Larreche. 2000, hal 17. Manajemen Pemasaran : Suatu Pendekatan Strategis dengan Orientasi Global, Edisi Kedua.Jakarta : Erlangga 
yang diberikan oleh manusia, baik yang dapat dilihat (explicit service), yang bisa dirasakan (implicit service) sampai pada fasilitasfasilitas pendukung yang harus tersedia dalam penjualan jasa dan benda-benda lainnya. ${ }^{6}$

Sebagai salah satu bentuk produk, jasa dapat didefinisikan sebagai setiap tindakan atau perbuatan yang dapat ditawarkan oleh suatu pihak lain yang pada dasarnya bersifat intangible (tidak berwujud fisik) dan tidak menghasilkan kepemilikan sesuatu. Jasa adalah intangible (seperti kenyamanan, hiburan, kecepatan, kesenangan, dan kesehatan) dan perishable (jasa tidak mungkin disimpan sebagai persediaan yang siap dijual atau dikonsumsi pada saat diperlukan) $)^{7}$.

Pemasaran jasa pendidikan merupakan salah satu dari kegiatan pokok yang dilakukan organisasi pendidikan untuk mempertahankan kelangsungan hidupnya, untuk berkembang, dan mendapatkan laba. Kegiatan pemasaran pendidikan harus dapat juga memberikan kepuasan kepada konsumen jika menginginkan usahanya berjalan terus, atau konsumen mempunyai pandangan yang baik terhadap lembaga pendidikan. Pemasaran pendidikan mencakup usaha lembaga pendidikan yang dimulai dengan mengidentifikasi kebutuhan konsumen yang perlu dipuaskan, menentukan produk yang hendak diproduksi, menentukan harga produk yang sesuai, menentukan cara-cara promosi dan bagaimana proses memproduksinya.

Bauran pemasaran jasa merupakan pengembangan bauran pemasaran. Menurut Lupiyoadi (2001) bahwa elemen Marketing Mix jasa terdiri dari tujuh hal, yaitu: Product (program jasa seperti apa yang ingin ditawarkan kepada konsumen), Price (bagaimana strategi penentuan harga), Place (bagaimana system penyampaian yang akan diterapkan), Promotion (bagaimana promosi yang harus dilakukan), People (tipe kualitas dan kuantitas orang yang akan terlibat dalam pemberian jasa), Process (bagaimana proses dalam operasi jasa), phisycal eveden (kelengkapan sarpras apa yang akan diberikan kepada konsumen). ${ }^{8}$

${ }^{6}$ Jasfar, Farida. 2005., Hal . 15. Manajemen Jasa: Pendekatan Terpadu. Bogor: Ghalia.

${ }^{7}$ Kotler, Philip. 2006, Hal. 16. Manajemen Pemasaran. Edisi 11. Jakarta: PT. Indeks

${ }^{8}$ Lupiyadi, Rambat. 2001, hal 30. Manajemen Pemasaran Jasa Teori dan Praktik. Jakarta : Salemba Empat 
b. Pemasaran Jasa Pendidikan

Menurut Kotler definisi pelayanan adalah setiap tindakan atau kegiatan yang dapat ditawarkan oleh suatu pihak kepada pihak lain, yang pada dasarnya tidak berwujud dan tidak mengakibatkan kepemilikan apapun. ${ }^{9}$ Produksinya dapat dikaitkan atau tidak dikaitkan pada satu produk fisik. Jasa merupakan aktivitas, manfaat atau kepuasan yang ditawarkan untuk dijual. Jasa berupa suatu kegiatan yang bermanfaat bagi pihak lain dalam memenuhi keinginan dan kebutuhannya. Kotler mengemukakan pengertian jasa adalah $a$ service to any act or performance that one party can offer to another that is essentially intangible and does not result in the ownership of anytihing. Its production may or may not tied to a physical pro$d u c t{ }^{10}$. Jasa merupakan sesuatu yang tidak berwujud, yang melibatkan hubungan antara penyaji jasa dengan konsumen pemakai dan tidak ada perpindahan kepemilikan (transfer of ownership) antara keduanya.

Apabila kita melihat lembaga pendidikan dari kacamata sebuah corporate, maka lembaga pendidikan ini adalah suatu organisasi produksi yang menghasilkan jasa pendidikan yang dibeli oleh para konsumen. Konsumen utamanya ialah para siswa, disamping itu masih banyak konsumen lain. Apabila produksen tidak mampu memasarkan hasil produksinya, dalam hal ini jasa pendidikan disebabkan karena mutunya tidak disenangi oleh konsumen, tidak memberikan nilai tambah bagi peningkatan pribadi individu, layanan tidak memuaskan, maka produksi jasa yang ditawarkan tidak akan laku. Akibatnya sekolah akan mundur peminatnya tidak ada, akhirnya sekolah itu ditutup.

Sasaran pemasaran lembaga pendidikan adalah calon peserta didik dan orang tua peserta didik, serta masyarakat luas pada umumnya. Masyarakat luas termasuk di dalamnya pengguna lulusan. Davies dan Ellison mengemukakan segmen pasar di sektor pendidikan meliputi pasar internal dan pasar eksternal. Pasar internal meliputi pengelola sekolah dan jajaran di atasnya, staf sekolah (guru dan tenaga kependidikan lainnya), pengawas, siswa yang sedang bersekolah orang tua siswa yang anaknya sedang bersekolah. Pasar eksternal meliputi calon siswa, calon orang tua siswa, alumni, calon

${ }^{9}$ Kotler, Philip 2003, hal. 83. Manajemen Pemasaran, Terjemahan Hendra Teguh, Ronny A, Rusli, Benjamin Molan, jilid 1 \& 2 edisi milenium, PT Prenhalindo, Jakarta

${ }^{10}$ Kotler, Philip 2003, Ibid , Halaman 444. 
staf, institusi pendidikan lainnya, masyarakat di sekitar sekolah, lembaga komersial dan industri, yayasan pendidikan, kantor standar dalam dunia pendidikan (di Indonesia seperti Badan Akreditasi Nasional dan Badan Akreditasi sekolah Dasar), Pusat Penataran Guru, kelompok-kelompok dan organisasi di tingkat nasional yang terkait dengan dunia pendidikan. ${ }^{11}$

c. Penerapan Bauran Pemasaran Pendidikan

Bauran pemasaran yang terdiri atas produk, harga, tempat dan promosi merupakan seperangkat alat pemasaran yang digunakan lembaga pendidikan untuk mencapai tujuan pasar sasaran. Selain itu, Best mengemukakan bahwa bauran pemasaran (marketing mix) merupakan bagian integral dari strategi bisnis yang memberikan arah pada semua fungsi manajemen sutu organisasi. ${ }^{12}$ Di dalam dunia pemasaran jasa pendidikan, Menurut Kotler dan Fox (2010: 56) menawarkan jasa dengan bauran pemasaran yang terdiri atas tujuh alat pemasaran, yang dikenal dengan 7P yaitu: Program (produk pendidikan), Price (harga), Place (tempat, meliputi lokasi dan sistem penyampaian jasa), Promotion (promosi), Process (proses), Phisical Facilities (fasilitas fisik/sarana prasarana), dan People (orang).

Faktor bauran pemasaran (marketing mix) juga berpengaruh terhadap keputusan pembelian oleh konsumen. Hal ini sependapat dengan Kotler, bahwa rangsangan pemasaran atau marketing stimuli yang terdiri atas produk, harga, tempat dan promosi masuk kedalam kesadaran pembeli dan akan mempengaruhi pengembilan keputusan pembelian. ${ }^{13}$ Ivy mengemukakan bahwa unsur-unsur bauran pemasaran layanan jasa pendidikan melalui 7Ps sangat diperlukan dalam membantu siswa mengambil keputusan. Siswa merasa terbantu dalam pengambilan keputusan dengan adanya bauran pemasaran jasa 7Ps. ${ }^{14}$

${ }^{11}$ Davies, B., dan Ellison, L., 1997. The New Strategic Direction and Development of The School: Key Framework for School Improvement Planning, Second Edition, RoutletgeFalmer, Taylor\&Francis Group, London

${ }^{12}$ Best, Rogers. 2000. Halaman :151. Market Based Management. Strategies for Growing, Customer Value and Profitability. Upper Saddle River New Jersey: Prentice Hall: 205-230.

${ }^{13}$ Kotler, Philip dan Amstrong, Gary. 2001, halaman : 160-161. Prinsipprinsip Pemasaran. Jilid Satu. Edisi Kedelapan. Jakarta: Erlangga

${ }^{14}$ Jonathan Ivy. 2010. Marketing Private EFL Program In Damascus, University of Lancaster management School. Tesol Journal Vol. 2, pp.130143 ISSN 2094-3938 


\section{Layanan}

Institusi pendidikan pada dasarnya dihadirkan untuk memberikan pelayanan kepada masyarakat pelanggan pendidikan. Dalam menjalankan fungsinya, institusi pendidikan memiliki ciri-ciri yang berbeda dengan organisasi bisnis, tetapi dalam menjalankan misi, tujuan dan programnya menganut prinsip-prinsip efisiensi, efektivitas, dan menempatkan masyarakat sebagai stakeholder yang harus dilayani secara optimal. Layanan kepada pelanggan pendidikan merupakan hak pelanggan yang pada dasarnya mengandung prinsip: kesederhanaan, kejelasan, kepastian waktu, akurasi, keamanan, tanggung-jawab, kelengkapan sarana, dan prasarana, kemudahan akses, kedisiplinan, kesopanan keramahan, dan kenyamanan. Hal ini seperti yang diungkapkan oleh Moenir bahwa hak atas pelayanan itu sifatnya sudah universal, berlaku terhadap siapa saja yang berkepentingan atas hak itu, dan oleh organisasi apapun juga yang tugasnya menyelenggarakan pelayanan. ${ }^{15}$

Lebih lanjut Moenir menyatakan (2002:27) pelayanan hakekatnya adalah serangkaian kegiatan, karena itu pelayanan juga merupakan sebuah proses, pelayanan berjalan secar rutin dan berkesinambungan meliputi seluruh kehidupan dalam masyarakat dan dilakukan secara profesiaonal.

Tjiptono (2005) menyatakan bahwa pelayanan merupakan proses yang terdiri atas serangkaian aktivitas intangible yang biasa (namun tidak harus selalu) terjadi pada interaksi antara pelanggan dan karyawan, jasa dan sumber daya, fisik atau barang, dan sistem penyedia jasa, yang disediakan sebagai solusi atas masalah pelanggan. Berdasarkan pengertian di atas maka dapat disimpulkan bahwa pelayanan merupakan suatu bentuk sistem, prosedur atau metode tertentu diberikan kepada orang lain, dalam hal ini, kebutuhan pelanggan tersebut dapat terpenuhi sesuai dengan harapan atau keinginan pelanggan dengan tingkat persepsi mereka. ${ }^{16}$

Penetapan sistem pelayanan mencakup strategi yang dilakukan, dimana pelayanan yang diberikan kepada pelanggan dapat merasakan langsung, agar tidak terjadi distorsi tentang suatu kepuasan

${ }^{15}$ Moenir, 2002. Hal. 41 Manajemen Pelayanan Umum Indonesia. Bumi Aksara. Jakarta Offset.

${ }^{16}$ Tjiptono, Fandy. 2005. Strategi Pemasaran Edisi II. Yogyakarta: Andi 
yang akan mereka terima. Sementara secara spesifik adanya peranan pelayanan yang diberikan secara nyata akan memberikan pengaruh bagi semua pihak terhadap manfaat yang dirasakan pelanggan.

Berkaitan dengan pemberian layanan kepada pelanggan pendidikan, maka lembaga harus mengutamakan dengan memberikan pelayanan yang berkualitas. Konsep kualitas layanan pada dasarnya memberikan persepsi secara konkrit mengenai kualitas suatu layanan. Konsep kualitas layanan ini merupakan suatu revolusi secara menyeluruh, permanen dalam mengubah cara pandang manusia dalam menjalankan atau mengupayakan usaha-usahanya yang berkaitan dengan proses dinamis, berlangsung, terus menerus di dalam memenuhi harapan, keinginan dan kebutuhan. Hal ini sesuai dengan teori "Quality" yang dikemukakan oleh Marcel bahwa keberhasilan suatu tindakan jasa ditentukan oleh kualitas. Kualitas merupakan apresiasi tertinggi dari tindakan pelayanan. ${ }^{17}$

Stemvelt menyatakan bahwa konsep kualitas layanan adalah suatu persepsi tentang revolusi kualitas secara menyeluruh yang terpikirkan dan menjadi suatu gagasan yang harus dirumuskan (formulasi) agar penerapannya (implementasi) dapat diuji kembali (evaluasi), untuk menjadi suatu proses yang dinamis, berlangsung, terus menerus dalam memenuhi kepuasan pelanggan. ${ }^{18}$ Teori "tujuan" yang dikembangkan oleh Samuelson bahwa tujuan adalah asumsi kepuasan yang disesuaikan dengan tingkat kualitas layanan. ${ }^{19}$

Konsep kualitas layanan pada dasarnya adalah suatu standar kualitas yang harus dipahami dalam memberikan pelayanan yang sebenarnya tentang pemasaran dengan kualitas layanan. Hal tersebut bukan hanya bersifat cerita atau sesuatu yang mengada-ada, tetapi harus disesuaikan dengan suatu standar yang layak, seperti standar ISO (International Standardization Organization), sehingga dianggap sebagai suatu kondisi yang sehat untuk tujuan atau pemakaian, memiliki keselarasan dengan spesifikasi, kebebasan dengan segala kekurangannya, membentuk kepuasan pelanggan, memiliki kredibilitas yang tinggi dan merupakan kebanggaan.

${ }^{17}$ Marcel, Davidson, 2003, hal 192. Service Quality in Concept and Theory. Published by American Press, USA

${ }^{18}$ Stemvelt, Robert C., 2004. Hal: 210. Perception of Service Quality. Allyn and Bacon, Massachusetts.

${ }^{19}$ Samuelson, Nordhaus. 2005. Hal. 84. Ekonomi. Terjemahan Jaka Wasana. Edisi Kedua belas. Erlangga, Jakarta. 
Gambar 2.1

Penilaian pelanggan pendidikan terhadap Kualitas layanan sekolah

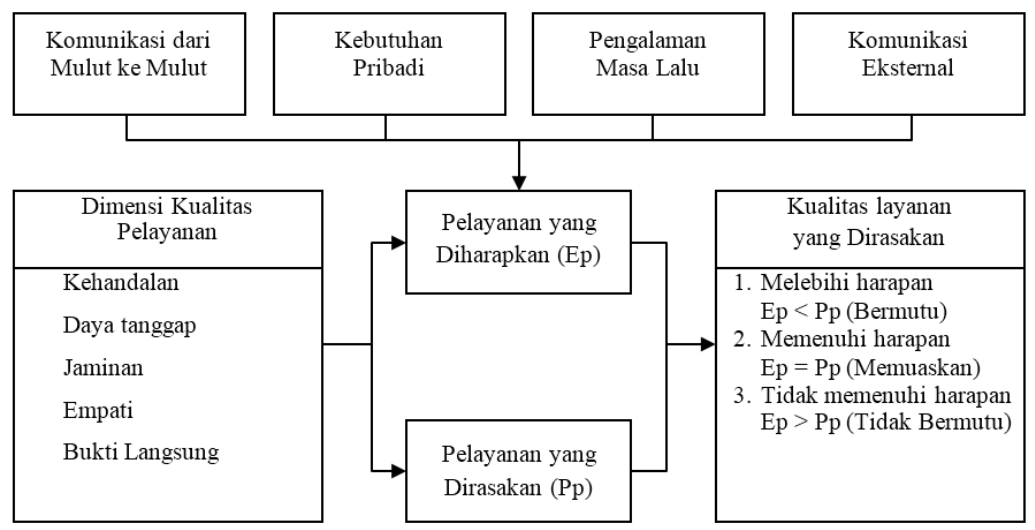

Sumber: Parasuraman (2001:162)

Tinjauan mengenai konsep kualitas layanan sangat ditentukan oleh berapa besar kesenjangan ( $\mathrm{gap}$ ) antara persepsi pelanggan atas kenyataan pelayanan yang diterima, dibandingkan dengan harapan pelanggan atas pelayanan yang harus diterima. Menurut Parasuraman bahwa konsep kualitas layanan yang diharapkan dan dirasakan ditentukan oleh kualitas layanan. Kualitas layanan tersebut terdiri dari daya tanggap, jaminan, bukti fisik, empati dan kehandalan. Selain itu, pelayanan yang diharapkan sangat dipengaruhi oleh berbagai persepsi komunikasi dari mulut ke mulut, kebutuhan pribadi, pengalaman masa lalu dan komunikasi eksternal, persepsi inilah yang mempengaruhi pelayanan yang diharapkan $(\mathrm{Ep}=$ Expectation $)$ dan pelayanan yang dirasakan $(\mathrm{Pp}=$ Perception $)$ yang membentuk adanya konsep kualitas layanan. ${ }^{20}$ Lebih jelasnya dapat ditunjukkan pada gambar di atas.

\section{Metode Penelitian}

Motode penelitian yang digunakan adalah penelitian pengembangan (Research and Development). Research and Development merupakan metode untuk melakukan penelitian, mengembangkan

${ }^{20}$ Zeithaml, Valerie A., Leonard L. Berry, and A. Parasuraman. 1996. Hal. 162 The Behavior Consequences of Service Quality. Jurnal of Marketing. Vol. 60 
dan menguji suatu produk. Dalam konteks pendidikan, maka produk yang dimaksud tersebut berkaitan dengan komponen sistem pendidikan. Penelitian dan pengembangan berupaya menghasilkan suatu komponen dalam sistem pendidikan, melalui langkah-langkah pengembangan dan validasi. ${ }^{21}$

Penelitian ini menggunakan metode R\&D dengan pendekatan kuantitatif dan kualitatif. Subyek penelitian ini adalah guru, komite, dan kepala MTs Swasta se Kota Semarang. Prosedur yang ditempuh selama penelitian ini meliputi: (1) Studi pendahuluan, (2) pengembangan, (3) validasi. Teknik pengambilan data menggunakan angket, obsevasi, dan wawancara. Teknik analisis data yang digunakan adalah deskriptif kuantitatif dan kualitatif serta validasi ahli.

\section{Deskrisi Data Faktual Model Manajemen Pemasaran Layanan Jasa Madrasah}

Penelitian yang dilaksanakan ini merupakan penelitian pengembangan manajemen pemasaran berbasis layanan jasa pendidikan di Madrasah Tsanawiyah Swasta se Kota Semarang. Adapun data faktual manajemen pemasaran berbasis layanan jasa pendidikan dapat dilihat dibawah ini:

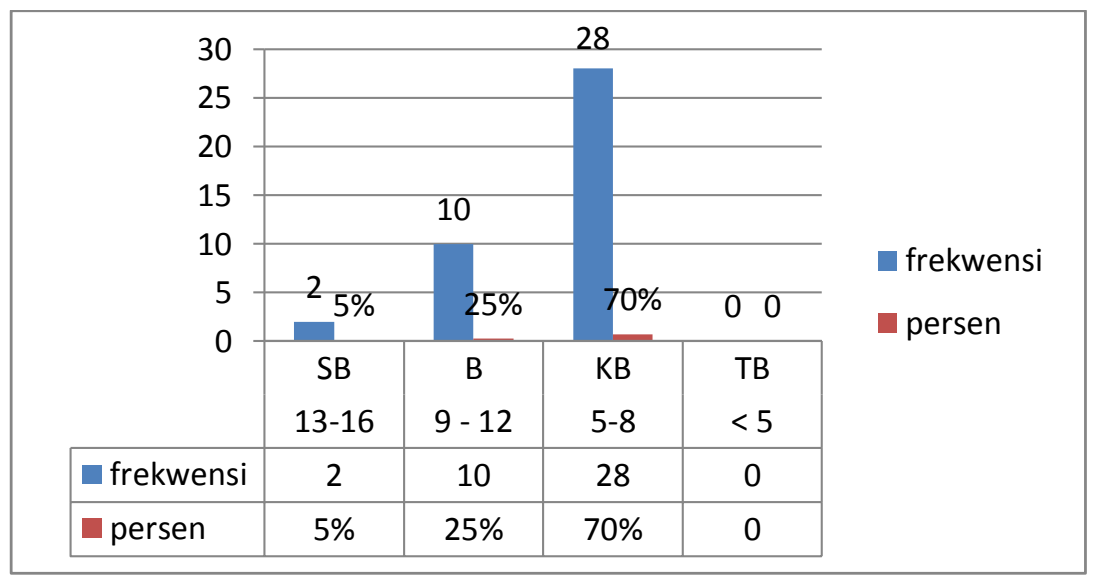

Berdasarkan hasil penelitian pendahuluan data faktual menunjukkan bahwa relevansi kurikulum tergolong dalam kategori

${ }^{21}$ Samsudi. 2006. Hal . 74. Disain Penelitian Pendidikan. Pekalongan: Universitas Negeri Pekalongan Press. 
kurang baik dengan persentasi skor 70\%, Kompetensi pendidik tergolong dalam kategori kurang baik dengan persentasi skor 78\%, tempat lingkungan pendidikan tergolong dalam kategori kurang baik dengan persentasi skor $70 \%$, tarif layanan madrasah tergolong dalam kategori kurang baik dengan persentasi skor $70 \%$, promosi madrasah tergolong dalam kategori kurang baik dengan persentasi skor $58 \%$, program madrasah tergolong dalam kategori kurang baik dengan persentasi skor 53\%, sarana dan prasarana tergolong dalam kategori kurang baik dengan persentasi skor $65 \%$, tenaga pendidikan tergolong dalam kategori kurang baik dengan persentasi skor $65 \%$, segmen pasar tergolong dalam kategori kurang baik dengan persentasi skor $70 \%$. Hal ini dapat diinterprestasikan bahwa responden menyatakan untuk manajemen pemasaran berbasis layanan pendidikan khusunya untuk indikator di atas di madrasah masih kurang baik atau memerlukan perbaikan.

a. Deskripsi data kebutuhan model manajemen pemasaran berbasis layanan jasa madrasah

Berdasarkan hasil penelitian kebutuhan model pemasaran manajemen jasa pendidikan menunjukkan bahwa relevansi kurikulum tergolong dalam kategori sangat penting dengan persentasi skor $73 \%$, kompetensi pendidik tergolong dalam kategori sangat penting dengan persentasi skor $75 \%$, tempat lingkungan pendidikan tergolong dalam kategori sangat penting dengan persentasi skor $63 \%$, tarif layanan madrasah tergolong dalam kategori sangat penting dengan persentasi skor 58\%, promosi madrasah tergolong dalam kategori sangat penting dengan persentasi skor $70 \%$, program madrasah tergolong dalam kategori sangat penting dengan persentasi skor $70 \%$, sarana dan prasarana tergolong dalam kategori sangat penting dengan persentasi skor $78 \%$, tenaga pendidikan tergolong dalam kategori sangat penting dengan persentasi skor $75 \%$, segmen pasar tergolong dalam kategori sangat penting dengan persentasi skor $75 \%$. 


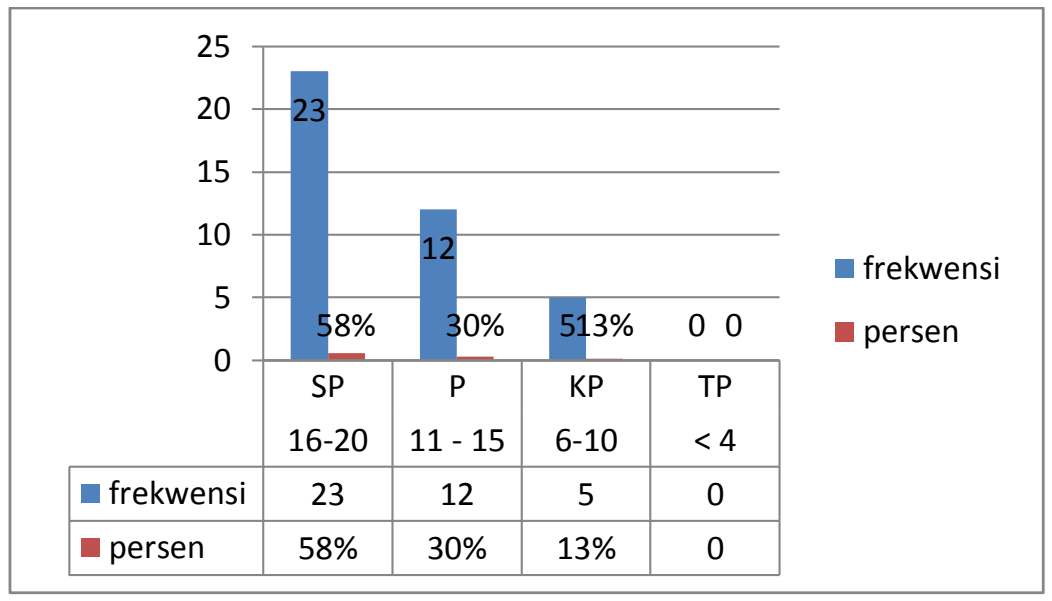

Berdasarkan hasil penelitian pendahuluan data faktual menunjukkan bahwa responden menyatakan untuk manajemen pemasaran berbasis layanan pendidikan khusunya untuk indikator di atas di madrasah masih kurang baik atau memerlukan perbaikan. Berkaitan dengan hasil penelitian tersebut bahwa model manajemen pemasaran yang selama ini dilakukan pada MTs Swasta Kota Semarang dapat digambarkan sebagai berikut:

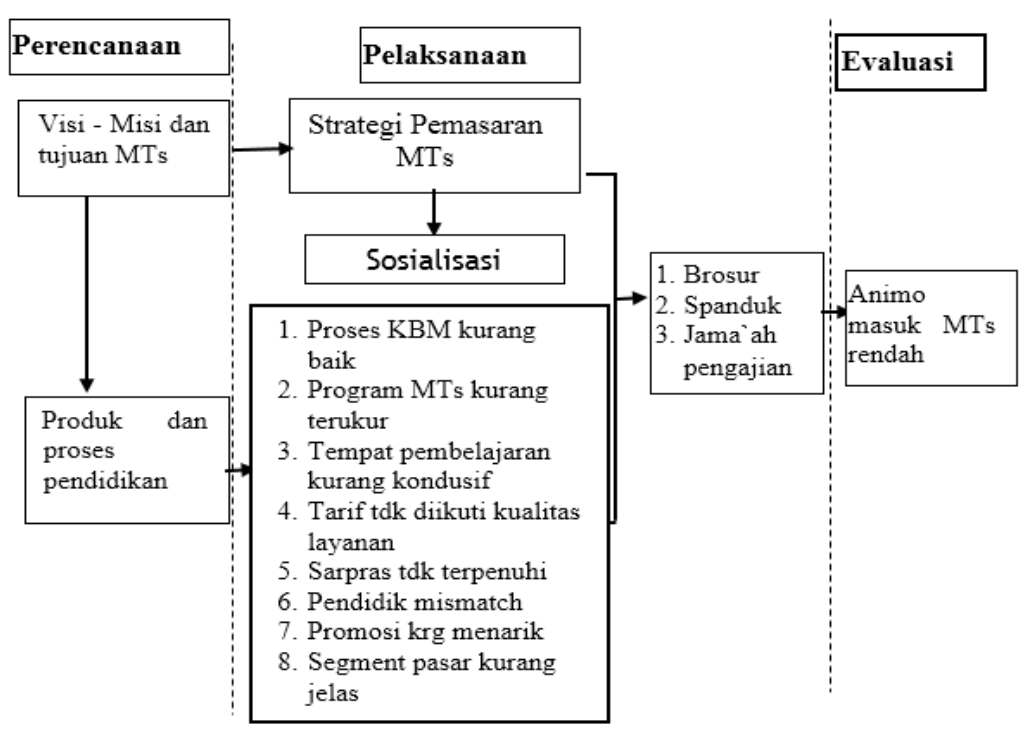

Gambar : 1. Model faktual manajemen pemasaran pada MTs Swasta se Kota Semarang 
Berdasarkan hasil uji kelayakan yang dilakukan oleh validator, MPBLP efektif meningkatkan kualitas layanan pendidikan. Secara teoretis, model final MPBLP merupakan temuan hasil proses pengembangan $R \& D$ yang teruji oleh validator denga skor 82 katagori sangat baik. Secara praktis, pengembangan model manajemen pemasaran pendidikan merupakan model yang dibutuhkan guna memperbaiki manajemen pemasaran pendidikan dan dapat digunakan untuk meningkatkan mutu layanan pendidikan. Rekomendasi pengembangan model ini dapat diimplementasikan oleh seluruh MTs Swasta dan MTs N. Selain itu respon madrasah yang tinggi terhadap model manajemen pemasaran pendidikan, mengimplikasikan perlunya model ini dikembangkan dengan spektrum yang lebih luas, skala sekolah yang bervariatif.

\section{Tabel 1 Hasil Penilaian validator Ahli}

\begin{tabular}{|c|c|c|c|c|c|c|c|c|c|}
\hline \multirow{2}{*}{ Aspek } & \multirow{2}{*}{ No } & \multirow{2}{*}{ Indikator } & \multicolumn{3}{|c|}{ Validator } & \multirow{2}{*}{ Rerata } & \multirow{2}{*}{ Katagori } & \multirow{2}{*}{ Rerata } & \multirow{2}{*}{ Ket } \\
\hline & & & 1 & 2 & 3 & & & & \\
\hline \multirow[t]{4}{*}{$\begin{array}{l}\text { Visualisasi } \\
\text { gambar } \\
\text { model }\end{array}$} & 1 & $\begin{array}{l}\text { Kelengkapan } \\
\text { komponen yang ada } \\
\text { dalam pelaksanaan } \\
\text { modul manajemen } \\
\text { pemasaran berbasis } \\
\text { layanan }\end{array}$ & 75 & 75 & 76 & 75 & Baik & & \\
\hline & 2 & $\begin{array}{l}\text { Kesesuain gambar } \\
\text { dengan konseptual } \\
\text { modul manajemen } \\
\text { pemasaran berbasis } \\
\text { layanan }\end{array}$ & 76 & 75 & 76 & 76 & Baik & 73,8 & Baik \\
\hline & 3 & $\begin{array}{l}\text { Keterbacaan gambar } \\
\text { sebagai } \\
\text { penyederhanaan dari } \\
\text { implementasi model } \\
\text { manajemen } \\
\text { pemasaran berbasis } \\
\text { layanan }\end{array}$ & 76 & 74 & 65 & 71,6 & Baik & & \\
\hline & 4 & $\begin{array}{l}\text { Keterbacaan gambar } \\
\text { mengenai harapan } \\
\text { funqsi manaiemen }\end{array}$ & 76 & 74 & 68 & 72,6 & Baik & & \\
\hline \multirow[t]{2}{*}{ Kejelasan } & 5 & $\begin{array}{l}\text { Alasan pentingnya } \\
\text { model manajemen } \\
\text { pemasaran berbasis }\end{array}$ & 80 & 65 & 66 & 65 & Baik & & \\
\hline & 6 & $\begin{array}{l}\text { layanan } \\
\text { Alasan keunggulan } \\
\text { dari modul } \\
\text { manajemen } \\
\text { pemasaran berbasis }\end{array}$ & 68 & 73 & 75 & 72 & Baik & 68,5 & Baik \\
\hline
\end{tabular}


Nadwa: Jurnal Pendidikan Islam | 83

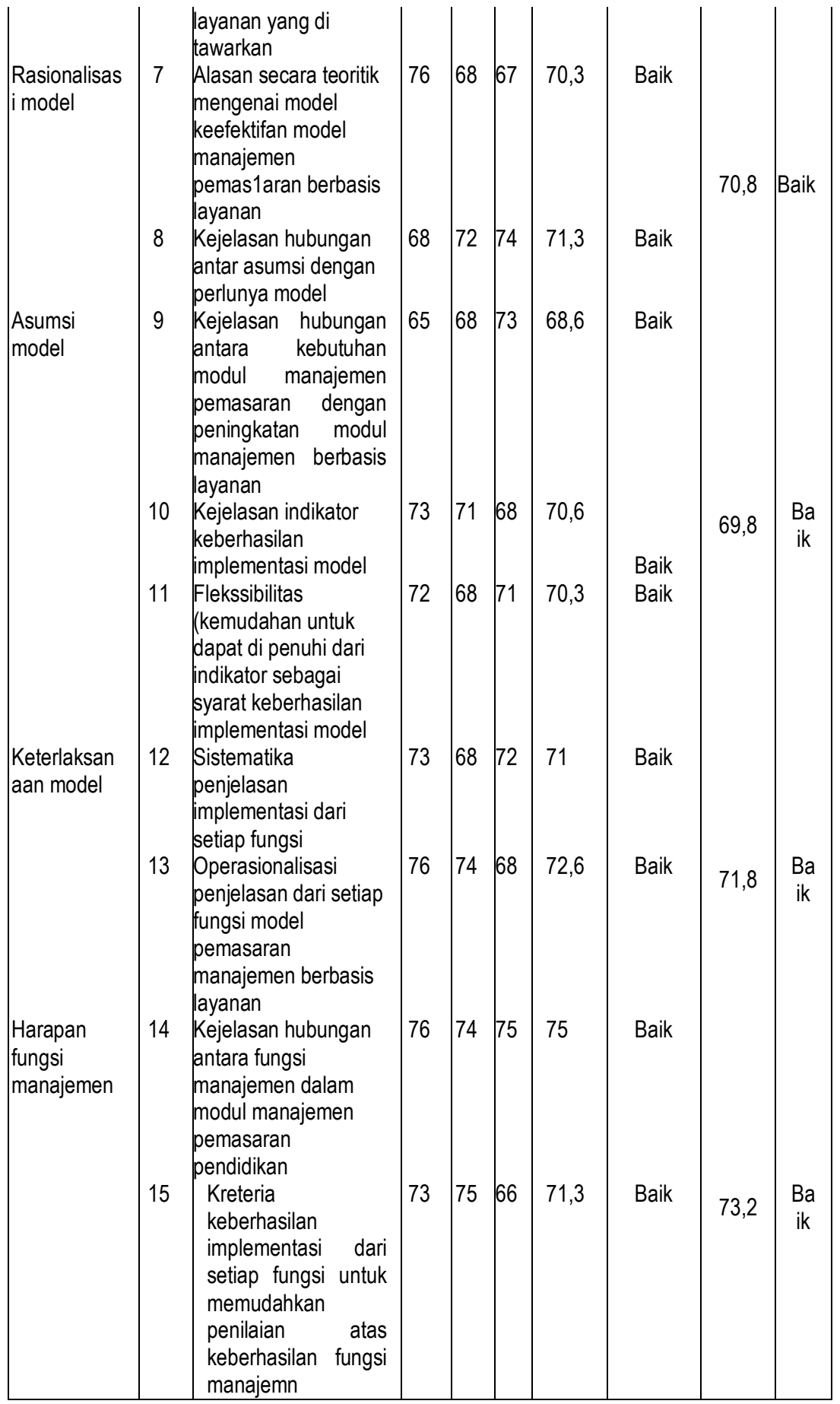


Berdasarkan hasil evaluasi validasi pakar, validasi praktisi, dan FGD sebagai uji coba secara luas, serta tanggapan dari praktisi mengenai pengembangan model manajemen pemasaran bebasis layanan jasa pendidikan pada MTs dalam kategori layak/baik. Konsep pengembagan model manajemen pemasaran berbasis layanan pendidikan berdasarkan hasil analisis deskriptif menunjukkan tingkat keberterimaan model untuk diselenggarakan dalam lingkungan madrasah Tsanawiyah se Kota Semarang.

Aspek penilaian visualisasi gambar model manajemen pemasaran berbasis layanan jasa pendidikan diperoleh rerata skor 73,8 . Hal ini menunjukkan secara umum bahwa penilaian perserta terhadap model manajemen pemasaran berbasis layanan jasa pendidikan katagori baik. Aspek penilaian kejelasan model manajemen pemasaran berbasis layanan jasa pendidikan diperoleh rerata skor 68,5. Hal ini menunjukkan secara umum bahwa penilaian perserta terhadap model manajemen pemasaran berbasis layanan jasa pendidikan katagori baik.

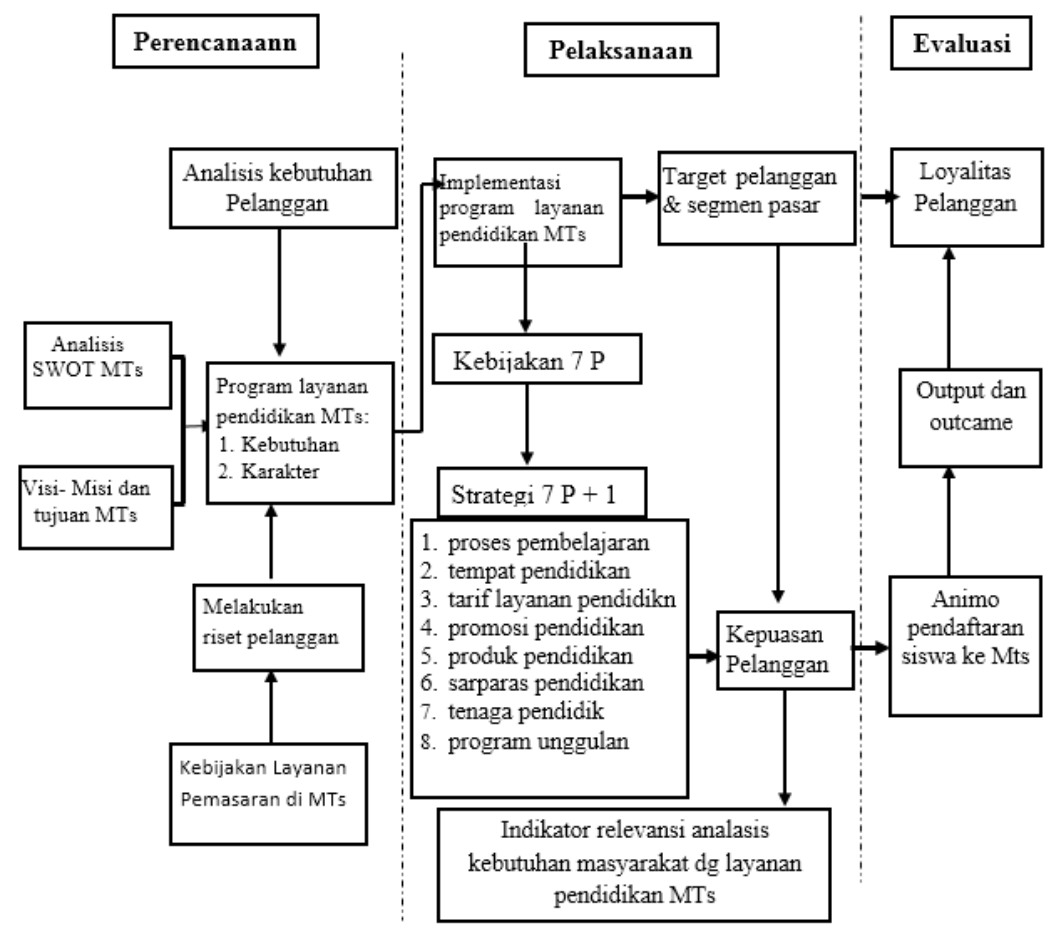

Gambar : 2. Desain model manajemen pemasaran pada MTs Swasta se Kota Semarang 
Aspek penilaian rasionalisasi model manajemen pemasaran berbasis layanan jasa pendidikan diperoleh rerata skor 70,8. Hal ini menunjukkan secara umum bahwa penilaian perserta terhadap model manajemen pemasaran berbasis layanan jasa pendidikan katagori baik. Aspek penilaian asumsi model manajemen pemasaran berbasis layanan jasa pendidikan diperoleh rerata skor 69,8. Hal ini menunjukkan secara umum bahwa penilaian perserta terhadap model manajemen pemasaran berbasis layanan jasa pendidikan katagori baik. Aspek penilaian keterlaksanaan model manajemen pemasaran berbasis layanan jasa pendidikan diperoleh rerata skor 71,8 . Hal ini menunjukkan secara umum bahwa penilaian perserta terhadap model manajemen pemasaran berbasis layanan jasa pendidikan katagori baik. Aspek penilaian harapan fungsi manajemen model manajemen pemasaran berbasis layanan jasa pendidikan diperoleh rerata skor 73,2. Hal ini menunjukkan secara umum bahwa penilaian perserta terhadap model manajemen pemasaran berbasis layanan jasa pendidikan katagori baik. Adapun desain model manajemen pemasaran bebasis layanan pendidikan pada MTs Swasta Se Kota Semarang sebagaimana pada gambar di atas.

\section{Penutup}

Simpulan penelitian ini dirangkum dari hasil pembahasan secara umum untuk menjawab pertanyaan penelitian. Berikut simpulan hasil penelitian:

1. Model majamen pemasaran berbasis layanan pendidikan sebelum penelitian diselengarakan tanpa terlebih dahulu dilakukan analisa kebutuhan, kurang memperhatikan perencanaan yang matang dan tidak melakukan evaluasi. seperti (1) strategi pemasaran layanan jasa proses pembelajaran yang kurang menarik (tidak menggunakan strategi pembelajaran, dan pengelolaan kelas), (2) jaminan dari produk pendidikan tidak terukur dengan jelas, (3) biaya pendidikan tidak diikuti dengan kualitas layanan, (4) tempat pendidikan kurang nyaman, kurang bersih dan tidak strategis), (5) promosi yang disampaikan MTs kurang meyakinkan masyarakat, (6) masih banyak staf pengajar tidak sesuai dengan kualifikasi, (7) kurang serius dalam mengarap sengemen pasar dan target pelanggan MTs (8) sarana dan prasarana kurang mencukupi, sehingga pemasaran layanan jasa pendidikan yang kurang baik tersebut berpengaruh terhadap 
kepuasan dan rendahnya minat pelanggan pendidikan ke Madrasah Tsanawiyah Swasta.

2. Desain model manajemen pesamaran berbasis layanan jasa pendidikan ini dikembangkan berdasarkan data penelitian kondisi faktual, kajian literature dan hasil analisis studi kebutuhan madrasah. Hal ini dapat dilihat dari (1) berdasarkan angket kebutuhan manajemen pesamaran berbasis layanan jasa pendidikan menunjukkan hasil validasi validator ahli dan praktisi dimana skor nilai 81 dalam katagori tinggi; (2) berdasarkan hasil kebutuhan disusun model manajemen pesamaran berbasis layanan jasa pendidikan yang layak diterapkan dan efektif sesuai dengan harapan madrasah. Bentuk awal model manajemen pesamaran berbasis layanan jasa pendidikan yang dikembangkan meliputi tiga tahap yaitu : pertama perencanaan yang terdiri dari (1) analisis kebutuhan pelanggan, (2) menetapkan program layanan MTs dengan memperhatikan kebutuhan dan karakter pelanggan, (3) melakukan analisis SWOT MTs, (4) memperhatikan visi, misi dan tujuan MTs, dan (5) kejelasan kebijakan layanan pemasaran di MTs. Kedua pelaksanaan terdiri atas (1) mengimplementasikan program layanan pendidikan MTs, (2) kebijakan strategi pemasaran pendidikan melalui $7 \mathrm{P}+$ program unggulan, (3) memperhatikan kepuasan pelanggan, (4) target pelanggan dan segmen pasar yang jelas, (5) memperhatikan indikator relevansi analasis kebutuhan masyarakat dengan layanan pendidikan MTs. Ketiga evaluasi meliputi bagaimana animo siswa masuk ke MTs, bagaimana output dan outcame serta loyalitas pelanggan pada MTs tersebut. Tingkat kesesuaian konseptual bentuk model manajemen pemasaran berbasis layanan jasa pendidikan madrasah ini valid setelah melakukan FGD terbatas kepada para praktisi serta mendapatkan penilaian baik.

Adapun saran yang bisa disampaikan adalah sebagai berikut:

1. Perlunya pihak Kementrian Agama Kota Semarang memberikan pembekalan yang lebih intensif bagi madrasah binaannya untuk meningkatkan layanan jasa pendidikan yang efektif dan efesian dalam rangka memberikan layanan prima pada peserta didik. Cara yang dapat dilakukan adalah (1) mengadakan pengembangan diri melalui pelatihan model-model pembelajaran, (2) mengadakan pelatihan karya inovatif, publikasi ilmiah, (3) 
melaksanakan pameran pendidikan MTs Swasta Se Kota Semarang dalam rangka memotivasi antar madrasah, (3) mengadakan kompetisi menentukan MTs unggulan/berprestasi sehingga dapat memotivasi MTs mengembangkan memenajemen pemasaran layanan jasa pendidikan yang efektif dan efesien serta berorientasi pada kepuasan pelangan MTs

3. Kepada Kepala madrasah disarankan untuk melakukan pemetaan analisis kebutuhan pelanggan pendidikan sebagai dasar melaksanakan pemasaran layanan jasa pendidikan. Beberapa cara yang dapat dilakukan adalah (1) melakukan analisis SWOT terhadap jenis-jenis layanan jasa pendidikan, misalnya apakah program layanan tersebut sesuai kebutuhan masyarakat atau tidak, apa manfaat dari program tersebut bagi pelanggan,

(2) membuat kebijakan strategi pemasaran layanan pendidikan, (3) mengevaluasi relevansi analasis kebutuhan masyarakat dengan layanan pendidikan MTs, (4) melakukan riset/penelitian terhadap selera pelanggan pendidikan.

4. Respon kepala madrasah dan guru yang tinggi mengenai model manajemen pemasaran layanan jasa pendidikan, mengimplikasikan perlunya model ini dikembangkan dengan spektrum yang lebih luas, skala madrasah yang bervariatif, dan lokasi yang fleksibel.

\section{Kepustakaan}

A.A. Anwar Prabu Mangkunegara. 1998. Perilaku Konsumen, Eresco: Bandung

Adrian, 2004, Metode Mengajar Berdasarkan Tipologi Belajar Siswa, Artikel.

Alma, Buchari dan Ratih Hurriyati, 2008. Manajemen Corporate \& Strategi Pemasaran Jasa Pendidikan. Bandung: Alfabeta

Arisutha, Damartaji, 2005. Dimensi Kualitas Pelayanan. Penerbit Gramedia. Pustaka, Jakarta

Arief. 2007. Pemasaran Jasa dan Kualitas Pelayanan Bagaimana Mengelola Kualitas Pelayanan agar Memuaskan Pelangan. Bayumedia Publising

Basu Swastha dan Irawan. 2003. "Manajemen Pemasaran Modern", edisi kedua cetakan ke sebelas. Yogyakarta : Liberty Offset.

Basu Swastha. 2002. Manajemen Pemasaran. Edisi Kedua. Cetakan Kedelapan. Jakarta: Penerbit Liberty 
Berry, L.L, Parasuraman, A. and Zeithaml V., 1994. Improving Service Quality in America : Lessons Learned, Academy of Management Executive.

Best, Rogers. 2000. Market Based Management. Strategies for Growing, Customer Value and Profitability. Upper Saddle River New Jersey: Prentice Hall: 205-230.

Biong, H., 1993. Satisfaction \& Loyalty to Suppliers within Grocery Trade, Eropean Journal or Marketing Vol 27, p 21-28.

Binsardi dan Ekwulugo. 2003, "International marketing of british education: research on the students 'perception end the UK market. Journal international emairal marketing intellegensi end planning. Vol. 11. 3/4.

Bogdan, Robert. C. dan Biklen, Sari Knopp. 1990. Riset Kualitatif Untuk Pendidikan: Pengantar Teori dan Metode. Alih Bahasa: Munandir. Jakarta: Ditjen Dikti Depdikbud.

Bogdan, Robert. C. dan Biklen, Sari Knopp. 1982. Qualitative Research for Education: An Introduction to Theory and Methods. Boston: Allyn and Bacon. Inc

Boyd, Walker dan Larreche. 2000. Manajemen Pemasaran: Suatu Pendekatan Strategis dengan Orientasi Global, Edisi Kedua.Jakarta : Erlangga

Chai Lee Goi, 2009. A Review of Marketing Mix: 4Ps or More?. International Journal of Marketing Studies. vol 1 No 1 may

Cravens, David W, 2000, Strategic Marketing $6^{\text {th }}$ edition, Irwin McGraw Hill, exas. edition, John Wiley \& Sons inc, New York.

Cresswell, J. W. 1994. Research Design : Qualitative \& Quantitative Approach. California: Sage Publication Inc.

Darmesta, B.S (1984), Azas-azas Marketing, Edisi ke 3, Liberty Yogyakarta.

Daulay, Haidar Putra. 1998. Pesantren, Sekolah dan Madrasah (Tinjauan dari Sudut Kurikulum Islam). Disertasi (Tidak Dipublikasikan). Yogyakarta: PPS IAIN Sunan Kalijaga.

Davies, B., dan Ellison, L., 1997. The New Strategic Direction and Development of The School: Key Framework for School Improvement Planning, Second Edition, RoutletgeFalmer, Taylor\&Francis Group, London

Derektorat Pendidikan Madrasah dan Ponpes Dirjen Pendidikan Islam Kemenag, 2015. 